\section{Reduced Plant Populations Save Seed Costs Without Reducing Yield or Quality of 'Alltop' Turnip Greens}

\author{
Brian A. Kahn ${ }^{1}$ \\ Department of Horticulture and Landscape Architecture, Oklahoma State \\ University, Stillwater, OK 74078-0511
}

Additional index words. Brassica rapa (Rapifera Group), processing; spacing

\begin{abstract}
Growers of turnip 'greens [Brassica rapa L. (Rapifera Group)] are accustomed to planting 5.6 to $10 \mathrm{~kg}$ of seed per hectare. A study was conducted in 1985 to determine whether reduced plant populations could be used without reducing yield or quality for 'Alltop', a hybrid cultivar with relatively expensive seed. A trial planted on 4 Apr. showed that populations could be reduced from 64 to 33 plants $/ \mathrm{m}$ of row without reducing yield or quality. A second trial, planted on 30 Aug., used populations of 36, 26, and 16 plants $/ \mathrm{m}$ of row. Again, there were no statistically significant reductions in yield or quality as populations decreased. However, yields from the 36 and 16 plants/ m treatments differed by almost $7 \mathrm{t} \cdot \mathrm{ha}^{-1}$, indicating substantial variability. A conservative approach would be to use a population of 33 to 36 plants/m of row ( $\approx 725,400$ plants/ha) to provide a balance between seed costs and yield. This can be achieved by seeding rates of 2.2 to $2.8 \mathrm{~kg} \cdot \mathrm{ha}^{-1}$.
\end{abstract}

Turnip greens are grown both for fresh market and for processing. The crop is established by direct seeding in the field.

McFerran et al. (1962) seeded 'Shogoin' turnip greens at $3.4,6.7,10.1$, and 13.5 $\mathrm{kg} \cdot \mathrm{ha}^{-1}$ in Arkansas. These seeding rates had no effect on total yields. However, leaf greenness decreased and percentage of leaf blade relative to petioles increased as seeding rates increased from 3.4 to $13.5 \mathrm{~kg} \cdot \mathrm{ha}^{-1}$. McFerran et al. (1962) recommended a planting rate of 6.7 to $10.1 \mathrm{~kg}$ of seed per hectare. Del Vane and Harmon (1970) seeded 'Shogoin' turnip greens at 2.8,5.6, and 11.2 $\mathrm{kg} \cdot \mathrm{ha}^{-1}$ in spring and fall trials in Georgia. As in the McFerran et al. (1962) study, seeding rates had no effect on total fresh weight yields. The percentage of leaf blade relative to petioles also was not affected by seeding rate, although leaves were an undesirable light green with the $11.2 \mathrm{~kg} \cdot \mathrm{ha}^{-1}$ rate.

On the basis of studies such as these, growers of turnip greens are accustomed to planting 5.6 to $10 \mathrm{~kg}$ of seed per hectare. The advent of hybrid turnip green cultivars has led to questions about the necessity for such high seeding rates. Hybrid cultivars, such as 'Alltop', have the potential to out-

Received for publication 25 Jan. 1989. Journal Article no. J-5547 of the Agr. Expt. Sta., Oklahoma State Univ., Stillwater. This research was supported in part by a grant from Stilwell Foods, Inc., Stilwell, Okla. The information given in this publication is for educational purposes only. Mention of a trademark, proprietary product or vendor does not constitute a guarantee or warranty of the product nor does it imply approval or disapproval to the exclusion of other products or vendors that may also be available. The cost of publishing this paper was defrayed in part by the payment of page charges. Under postal regulations, this paper therefore must be hereby marked advertisement solely to indicate this fact.

Associate Professor.

${ }^{2}$ Harvests 43 and 60 days after planting, respectively. 'Populations averaged over the four rows per bed. fine sandy loam [coarse-silty, mixed (calcareous), thermic Typic Udifluvents]. A preplant-incorporated application of 2,6-dinitro$\mathrm{N}$, N, -dipropyl-(trifluoromethyl)benzenamine (trifluralin) at $560 \mathrm{~g} \cdot \mathrm{ha}^{-1}$ was made before each experiment to control weeds. Standard commercial foliar insecticides, including a Bacillus thuringiensis Berliner product, and fungicides, including a fixed copper product, were used.

Plots $4 \mathrm{~m}$ long were established on beds that were $1.93 \mathrm{~m}$ wide. Four Stanhay precision seeders (Hestair Farm Equipment, Exning, Newmarket, U.K.). planted four rows spaced $\approx 40 \mathrm{~cm}$ apart on each bed. In the spring study, each Stanhay belt had two rows of holes, creating two seedlines spaced 50 $\mathrm{mm}$ apart per planted row. There was a single seedline per row in the fall study. Seeding rates were $3 \mathrm{~kg} \cdot \mathrm{ha}^{-1}$ in the spring and $2.5 \mathrm{~kg} \cdot \mathrm{ha}^{-1}$ in the fall. Differential plant populations were established by leaving all four rows per bed unthinned or by removing $\approx 25 \%$ or $50 \%$ of the seedlings in a plot. Post-thinning and postharvest stand counts were made in each plot, and plant populations were expressed as the number of plants per meter of row averaged over the four rows per bed.

At harvest, plants in a $2.5-\mathrm{m}$ section of each row were cut by hand at $\approx 50 \mathrm{~mm}$ above the soil to obtain fresh weight yield. This procedure simulated the cutting height of a commercial mechanical harvester and permitted regrowth of the plants. Row sections of $0.30 \mathrm{~m}$ also were sampled to obtain additional data on plant responses. Yellow leaves were separated out and counted. Leaf fresh weights and numbers were recorded. Leaf areas were measured with a LI-COR Model 3100 area meter (LI-COR, Lincoln, Neb.). Leaves then were separated into petioles/ midribs and blades using a scalpel, and dried

Table 1. Plant growth and quality and yield characteristics of 'Alltop' turnip greens in response to plant population (Bixby, Okla., Spring 1985). Date of planting was 4 Apr. 1985.

\begin{tabular}{|c|c|c|c|c|c|c|c|c|}
\hline \multirow[b]{3}{*}{ Variable } & \multicolumn{3}{|c|}{ First harvest ${ }^{2}$} & & \multicolumn{3}{|c|}{ Second harvest ${ }^{\mathbf{z}}$} & \multirow[b]{3}{*}{$L^{x}$} \\
\hline & \multicolumn{3}{|l|}{-} & \multicolumn{4}{|c|}{ Population treatment ${ }^{y}$} & \\
\hline & 1 & 2 & 3 & $\mathrm{~L}^{x}$ & 1 & 2 & 3 & \\
\hline $\begin{array}{l}\text { Plants/m of row } \\
\text { after thinningw }\end{array}$ & 64 & 55 & 33 & * & 64 & 55 & 33 & $*$ \\
\hline Plants/m of row & & & & & & & & \\
\hline at harvestw & 49 & 46 & 30 & NS & 48 & 40 & 30 & $*$ \\
\hline $\begin{array}{l}\text { Leaf no./plant } \\
\text { Leaf area/ }\end{array}$ & 6.1 & 6.3 & 7.2 & NS & 4.3 & 4.9 & 5.8 & $*$ \\
\hline $\begin{array}{l}\text { plant }\left(\mathrm{cm}^{2}\right) \\
\text { Leaf fresh }\end{array}$ & 486 & 486 & 711 & NS & 296 & 347 & 500 & $*$ \\
\hline wt/plant (g) & 29 & 29 & 44 & NS & 15 & 18 & 27 & $*$ \\
\hline $\begin{array}{l}\text { Leaf dry wt }(\%) \\
\text { Percent blade }\end{array}$ & 8.4 & 8.6 & 8.5 & NS & 9.9 & 9.9 & 9.6 & NS \\
\hline $\begin{array}{l}\text { of leaves } \\
\text { Yellow leaves } \\
\text { (\% of total leaf }\end{array}$ & 48 & 50 & 51 & NS & 59 & 61 & 62 & NS \\
\hline $\begin{array}{l}\text { no./plant) } \\
\text { Yield, fresh }\end{array}$ & 3.9 & 3.6 & 2.5 & NS & 3.0 & 1.9 & 3.1 & NS \\
\hline wt $\left(\mathrm{t} \cdot \mathrm{ha}^{-1}\right)$ & 23.9 & 23.4 & 23.0 & NS & 14.5 & 14.0 & 15.6 & NS \\
\hline
\end{tabular}

${ }^{\text {y }}$ Plots consisted of four-row beds. $1=$ unthinned; $2=$ thinned $\approx 25 \% ; 3=$ thinned $\approx 50 \%$.

'Linear effect of population nonsignificant (NS) or significant at $P=0.05(*)$. Quadratic effects never were significant. Coefficients of variation for yield were $13 \%$ at first harvest and $20 \%$ at second harvest. 
Table 2. Plant growth and quality and yield' characteristics of 'Alltop' turnip greens in response to plant population (Bixby, Okla., Fall 1985). Date of planting was 30 Aug. 1985.

\begin{tabular}{|c|c|c|c|c|c|c|c|c|}
\hline \multirow[b]{3}{*}{ Variable } & \multicolumn{3}{|c|}{ First harvest $^{2}$} & & \multicolumn{3}{|c|}{ Second harvest ${ }^{2}$} & \multirow[b]{3}{*}{$L^{x}$} \\
\hline & \multicolumn{7}{|c|}{ Population treatmenty } & \\
\hline & 1 & 2 & 3 & $\mathrm{~L}^{\mathrm{x}}$ & 1 & 2 & 3 & \\
\hline $\begin{array}{l}\text { Plants/m of row } \\
\text { after thinning }\end{array}$ & 36 & 26 & 16 & $* *$ & 36 & 26 & 16 & $* *$ \\
\hline Plants/m of row & 27 & 20 & 14 & * & 26 & 20 & 12 & * \\
\hline $\begin{array}{l}\text { Leaf no./plant } \\
\text { Leaf area/ }\end{array}$ & 7.3 & 8.8 & 8.6 & NS & 6.4 & 7.1 & 8.6 & NS \\
\hline $\begin{array}{c}\text { plant }\left(\mathrm{cm}^{2}\right) \\
\text { Leaf fresh }\end{array}$ & 963 & 1420 & 1710 & * & 685 & 863 & 1230 & NS \\
\hline wt/plant (g) & 63 & 97 & 125 & * & 41 & 54 & 79 & NS \\
\hline $\begin{array}{l}\text { Leaf dry wt }(\%) \\
\text { Percent blade }\end{array}$ & 6.1 & 6.0 & 6.1 & NS & 7.4 & 7.4 & 7.6 & NS \\
\hline $\begin{array}{c}\text { of leaves } \\
\text { Yellow lcaves }\end{array}$ & 48 & 49 & 51 & NS & 58 & 59 & 61 & NS \\
\hline $\begin{array}{c}\text { (\% of total leaf } \\
\text { no./plant) }\end{array}$ & 5.5 & 4.8 & 1.5 & $* *$ & 0.4 & 1.3 & 2.0 & NS \\
\hline $\begin{array}{l}\text { Yield, fresh } \\
\text { wt }\left(t \cdot h a^{-1}\right)\end{array}$ & 35.0 & 31.3 & 28.1 & NS & 18.6 & 16.1 & 17.2 & NS \\
\hline
\end{tabular}

${ }^{2}$ Harvests 47 and 75 days after planting, respectively.

'Plots consisted of four-row beds. $1=$ unthinned; $2=$ thinned $=2570 ; 3=$ thinned $\approx 50 \%$.

${ }^{x}$ Linear effect of population nonsignificant (NS) or significant at $P=0.05(*)$ or 0.01 (**). Quadratic effects never were significant. Coefficients of variation for yield were $15 \%$ at first harvest and $8 \%$ at second harvest.

'Populations averaged over the four rows per bed.

at 50C. Percent blade of leaves was expressed on a dry-weight basis, and percent dry weight of leaves was calculated.

The experimental design was a randomized complete block with four replications. Data were analyzed with an analysis of variance. Linear and quadratic population effects were examined using trend analysis.

Soil for the Spring 1985 experiment was prepared with a broadcast, preplant-incorporated application of $45 \mathrm{~kg} \mathrm{~N} / \mathrm{ha}$. A soil test indicated that adequate $\mathrm{P}$ and $\mathrm{K}$ were available from fertilization of previous trials. Seeds were planted on 4 Apr., and seedlings were thinned by hand on 24 Apr. All water needs were met by rainfall. Plants were topdressed with $56 \mathrm{~kg} \mathrm{~N} / \mathrm{ha}$ on 2 May. The first harvest was on 17 May. Plants were topdressed with $56 \mathrm{~kg} \mathrm{~N} / \mathrm{ha}$ on 22 May, and the second harvest was on 3 June. Minimum, maximum, and average air temperatures during the experimental period were 6,32 , and $19 \mathrm{C}$, respectively, with a rainfall total of $212 \mathrm{~mm}$.

Soil for the Fall 1985 experiment was preirrigated and prepared with a broadcast, preplant-incorporated application of $56 \mathrm{~kg} \mathrm{~N} /$ ha. Again, adequate $\mathrm{P}$ and $\mathrm{K}$ were available from fertilization of previous trials. Seeds were planted on 30 Aug. Plots were sprinkler-irrigated daily from 31 Aug. through 5 Sept. Seedlings were thinned by hand on 9 Sept. The first harvest was on 16 Oct. Plants were topdressed with $62 \mathrm{~kg} \mathrm{~N} / \mathrm{ha}$ on 25 Oct., and the second harvest was on 13 Nov. Minimum, maximum, and average air temperatures during the experimental period were $0.5,38$, and $18 \mathrm{C}$, respectively. The rainfall total was $339 \mathrm{~mm}$, with $265 \mathrm{~mm}$ recorded during October alone.

There were significant differences in plant population after thinning in the Spring 1985 experiment (Table 1). However, these differences had disappeared by the first harvest due to plant loss in the high population treatments. As a result, there were no differences in leaf-related variables or in yield at the first harvest (Table 1). Further attrition of plants reestablished significant population differences at the second harvest. Leaf number, area, and fresh weight per plant showed linear increases with decreasing population at the second harvest. However, quality attributes and yield per hectare remained unaffected by population (Table 1).

The lowest population used in the Spring 1985 experiment was targeted as the highest population for the Fall 1985 experiment to study the effects of very low plant populations ( $<20$ plants/m of row) on yield and quality. Despite these low initial populations, plant loss still occurred between thinning and first harvest (Table 2). Interplant competition may have been more severe than in the spring study due to the hot, dry weather typical of early September in Oklahoma. As in the spring study, the plants tended to compensate for the extra space at low populations by increasing leaf area and leaf fresh weight. Increases in leaf number were not significant in the fall (Table 2). Once again, quality attributes were unaffected by population, with the exception of percent yellow leaves at the first harvest (Table 2). Yields from the 36 and 16 plants/m treatments differed by almost $7 \mathrm{t} \cdot \mathrm{ha}^{-1}$ at first harvest. This yield difference was not statistically significant due to substantial variability (Table 2). However, a yield difference of $7 \mathrm{t} \cdot \mathrm{ha}^{-1}$ wotddrepresent a difference of about $\$ 456 /$ ha (based on a price of about $\$ 66 / t$ of greens for freezing), which growers would consider significant.

Yield and quality of 'Alltop' turnip greens were unaffected by plant populations obtained using seeding rates well below 5.6 $\mathrm{kg} \cdot \mathrm{ha}^{-1}$. A population of 33 to 36 plants $/ \mathrm{m}$ of row, in a four-row bed system, may provide a good balance between seed costs and yield. This is equivalent to $\approx 725,400$ plants/ ha. Higher initial populations are unlikely to be maintained through harvest due to plant loss and will not result in increased yields. Based on the fall data, a target population of 36 plants $/ \mathrm{m}$ of row still would provide a margin of safety if stand establishment is less successful than anticipated, in that somewhat lower stands may not result in significant yield reductions. On the basis of these studies and grower experience (D. Smith, personal communication), a population of 33 to 36 plants/m of row maybe achieved by seeding rates of 2.2 to $2.8 \mathrm{~kg} \cdot \mathrm{ha}^{-1}$. Individual growers will develop their own seeding rates, contingent upon factors such as season and soil type.

\section{Literature Cited}

Del Vane, C.G. and S.A. Harmon. 1970. Influence of seeding rate, source and level of nitrogen, on yield, color, leaf blade weight, and nitrogen content of turnip greens. J. Amer. Sot. Hort. Sci. 95(1):62-64.

McFerran, J., J.L. Bowers, and H.H. Vose. 1962. Seeding rates for the greens crops. Ark. Farm Res. 11(3):10. 